\section{International Scientific Journal Theoretical \& Applied Science}

p-ISSN: 2308-4944 (print) $\quad$ e-ISSN: 2409-0085 (online)

Year: 2017 Issue: 12 Volume: 56

Published: $30.12 .2017 \quad$ http://T-Science.org

SECTION 2. Applied mathematics. Mathematical modeling.
Seytkhan Koybakov

doctor of technical Sciences, Professor, academician of International Academy of Sciences of

Ecology and Life Safety,

Pro-rector on scientific work and international relations,

Taraz State University named after M.Kh. Dulati,

Kazakhstan

seithan@tarazinfo.kz

\section{Muratzhan Maliktayuly} doctoral student,

Taraz State University named after M.Kh. Dulati

Alexandr Shevtsov candidate of technical sciences, member of PILA (USA), department of «Mathematics», deputy director on Science of faculty of Information technologies, automation and telecommunications, Taraz state University named after M.Kh. Dulati Shev_AlexXXXX@mail.ru

\title{
SIMULATION MODELS OF CHAOTIC FLOW
}

Abstract: This paper discusses options of modelling the dynamic characteristics of the process of the aerodynamic flow around the bed of the channel, in a flat non-steady model of turbulent flow. The obtained data about the pressure and speed of flow at various speeds and when the wind gusts up to $40 \mathrm{~m} / \mathrm{s}$.

Key words: wind, channel, flow, turbulence

Language: English

Citation: Koybakov S, Maliktayuly M, Shevtsov A (2017) SIMULATION MODELS OF CHAOTIC FLOW. ISJ Theoretical \& Applied Science, 12 (56): 87-92.

Soi: http://s-o-i.org/1.1/TAS-12-56-16 Doi: crossef https://dx.doi.org/10.15863/TAS.2017.12.56.16

\section{Introduction}

Most of the territory of Kazakhstan is exposed to high winds that cause snow and sand drifts. Water conveyance channels, operated in these conditions, reduce bandwidth up to a full stop. The reason for the drift are turbulent air streams arise in the mainstream channel. Consider a mathematical model simulating the flow of air, full of snow or sand particles impinging on the bed of the canal [1].

\section{Materials and Methods}

For the simulation of laminar and turbulent air flows with a mixture of different complexes is used: Comsol, Flowvision and others. For modeling laminar and turbulent flows of air mixed with particles of snow or sand using various complexes: Comsol, Flowvision and others.

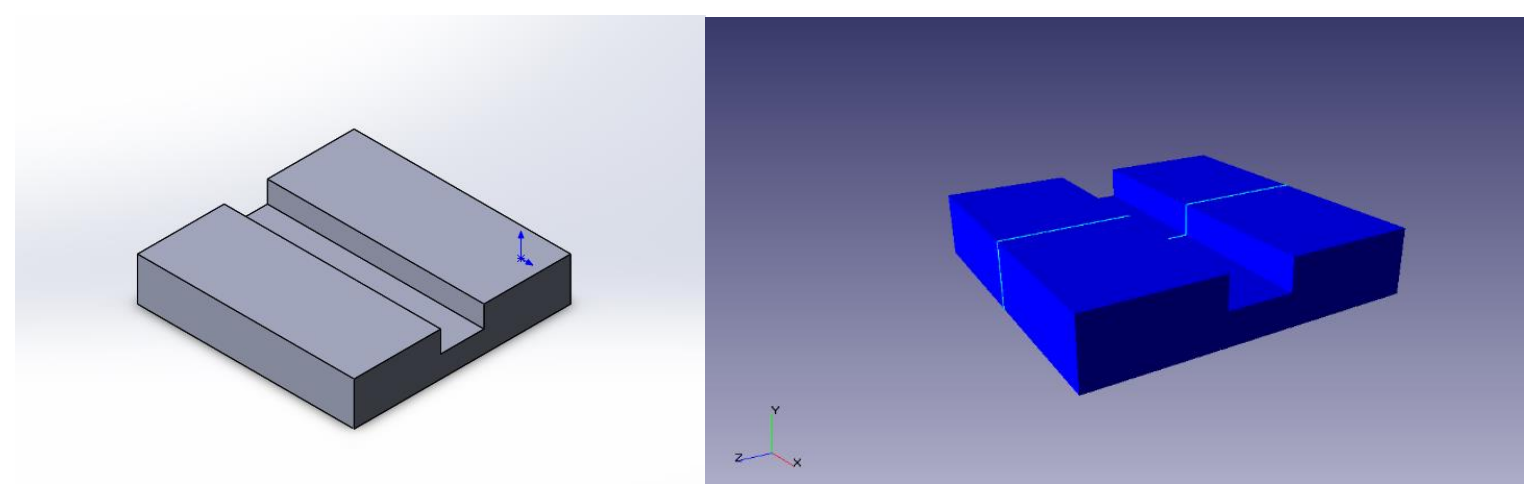

Picture 1 - Geometry.

ISPC Generalization of scientific results, Philadelphia, USA 


\begin{tabular}{l|lr|ll|ll} 
& ISRA (India) & $=\mathbf{1 . 3 4 4}$ & SIS (USA) & $=\mathbf{0 . 9 1 2}$ & ICV (Poland) & $=\mathbf{6 . 6 3 0}$ \\
Impact Factor: & ISI (Dubai, UAE) & $=\mathbf{0 . 8 2 9}$ & PUHL (Russia) & $=\mathbf{0 . 2 0 7}$ & PIF (India) & $=1.940$ \\
& GIIF (Australia) & $=\mathbf{0 . 5 6 4}$ & ESJI (KZ) & $=4.102$ & IBI (India) & $=4.260$ \\
& JIF & $=\mathbf{1 . 5 0 0}$ & SJIF (Morocco) $=\mathbf{2 . 0 3 1}$ & & \\
\hline
\end{tabular}

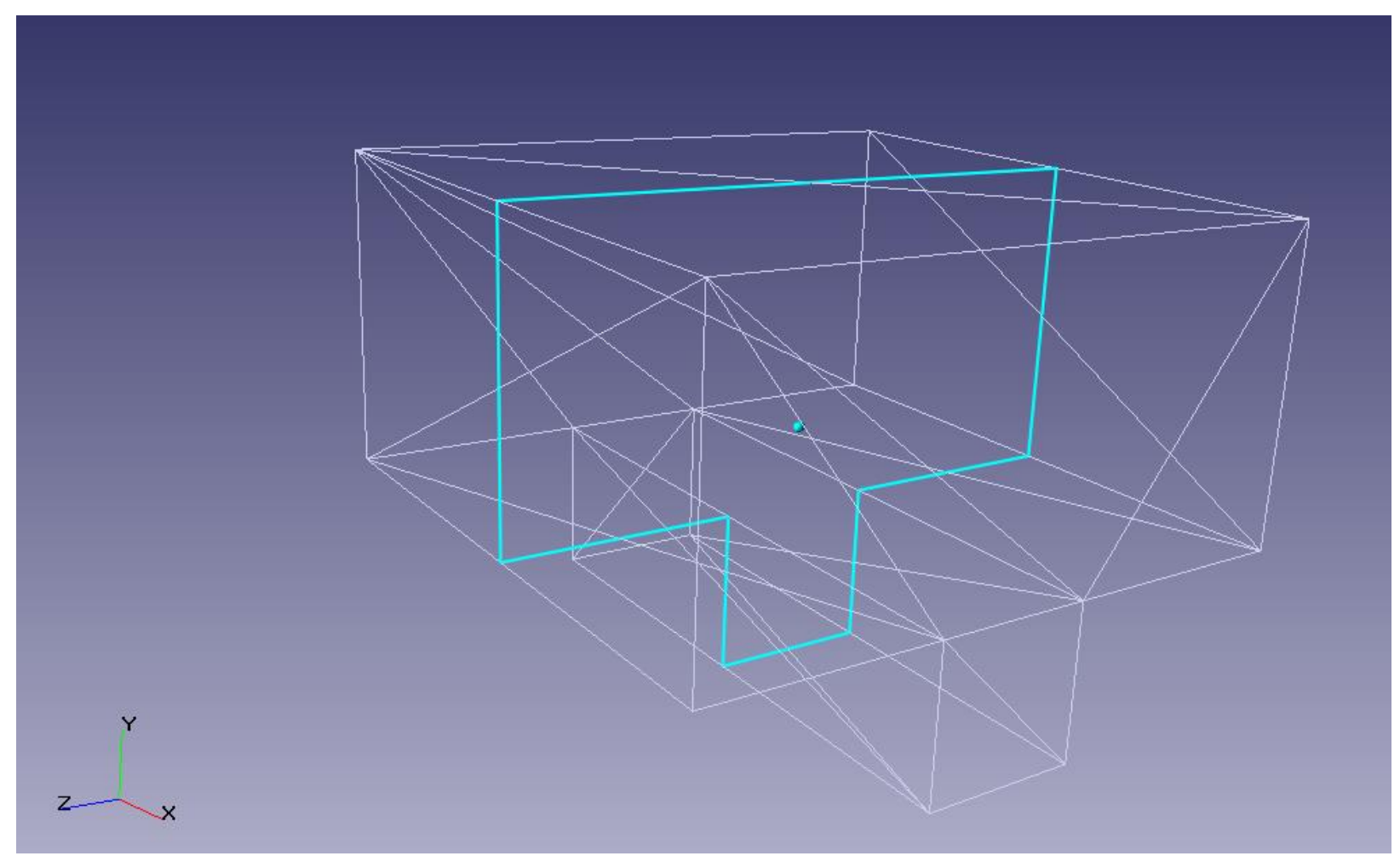

Picture 2 - Grid of model.

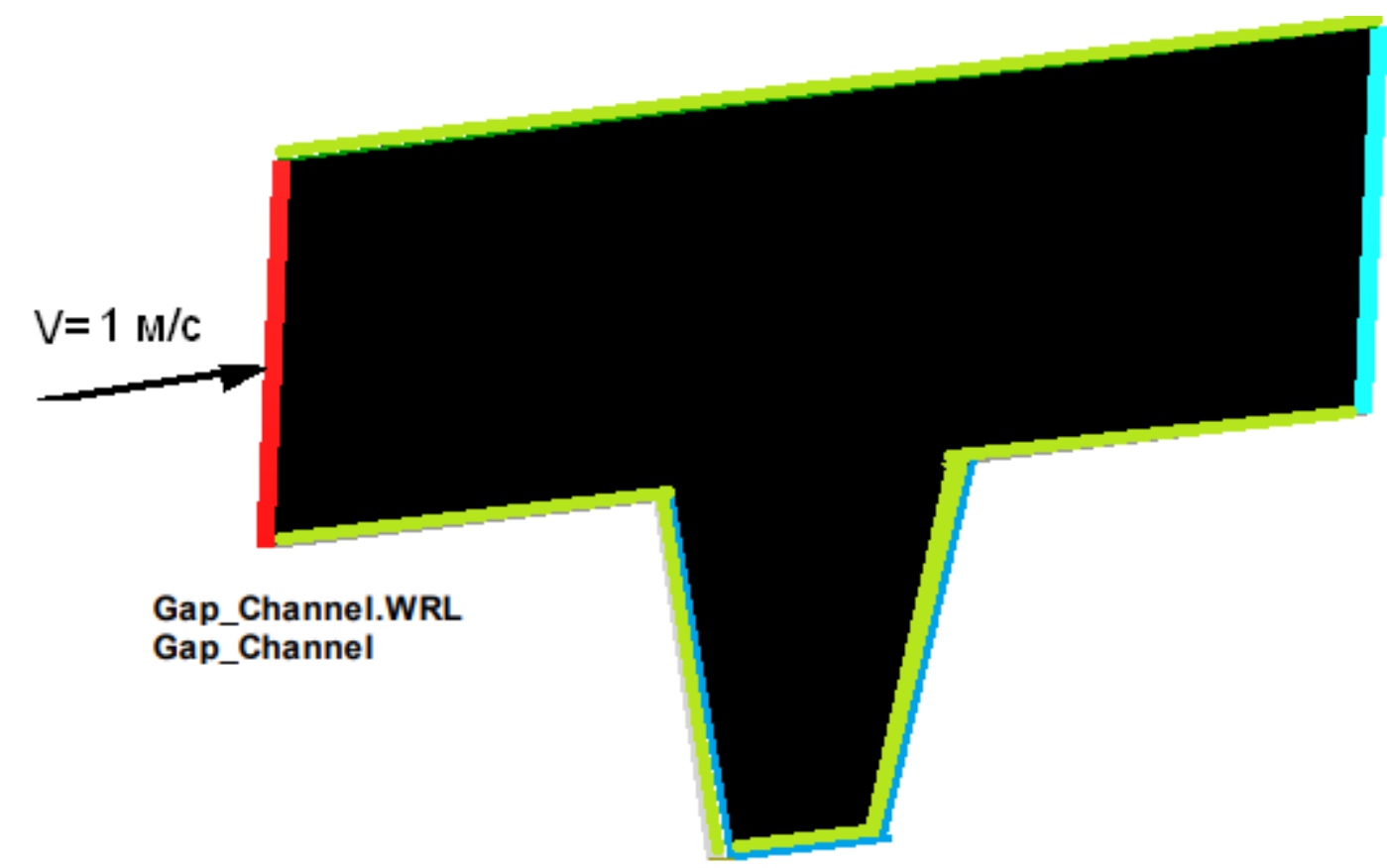

Picture 3 - The flow in the channel using a model of the gap.

In this model we consider the simulation of the flow in a narrow two-dimensional channel with using the model of the gap.

The gap model is used in conjunction with a given model of the flow and is designed to account for resistance created by a narrow channel. The gap model allows to avoid the resolution of narrow channel grid. The gap model is only used in cells of the gap. The cell gap of the cell, between the 2 the gap-forming surfaces. Surfaces are the gap-forming, if the distance between them does not exceed a predetermined maximum value gap. The cell gap is determined FlowVision automatically. 


\begin{tabular}{l|lr|ll|ll} 
& ISRA (India) & $=\mathbf{1 . 3 4 4}$ & SIS (USA) & $=\mathbf{0 . 9 1 2}$ & ICV (Poland) & $=\mathbf{6 . 6 3 0}$ \\
Impact Factor: & ISI (Dubai, UAE) $=\mathbf{0 . 8 2 9}$ & PUHЦ (Russia) $=\mathbf{0 . 2 0 7}$ & PIF (India) & $=\mathbf{1 . 9 4 0}$ \\
& GIF (Australia) & $=\mathbf{0 . 5 6 4}$ & ESJI (KZ) & $=\mathbf{4 . 1 0 2}$ & IBI (India) & $=\mathbf{4 . 2 6 0}$ \\
& JIF & $=\mathbf{1 . 5 0 0}$ & SJIF (Morocco) & $\mathbf{2 . 0 3 1}$ & & \\
\hline
\end{tabular}
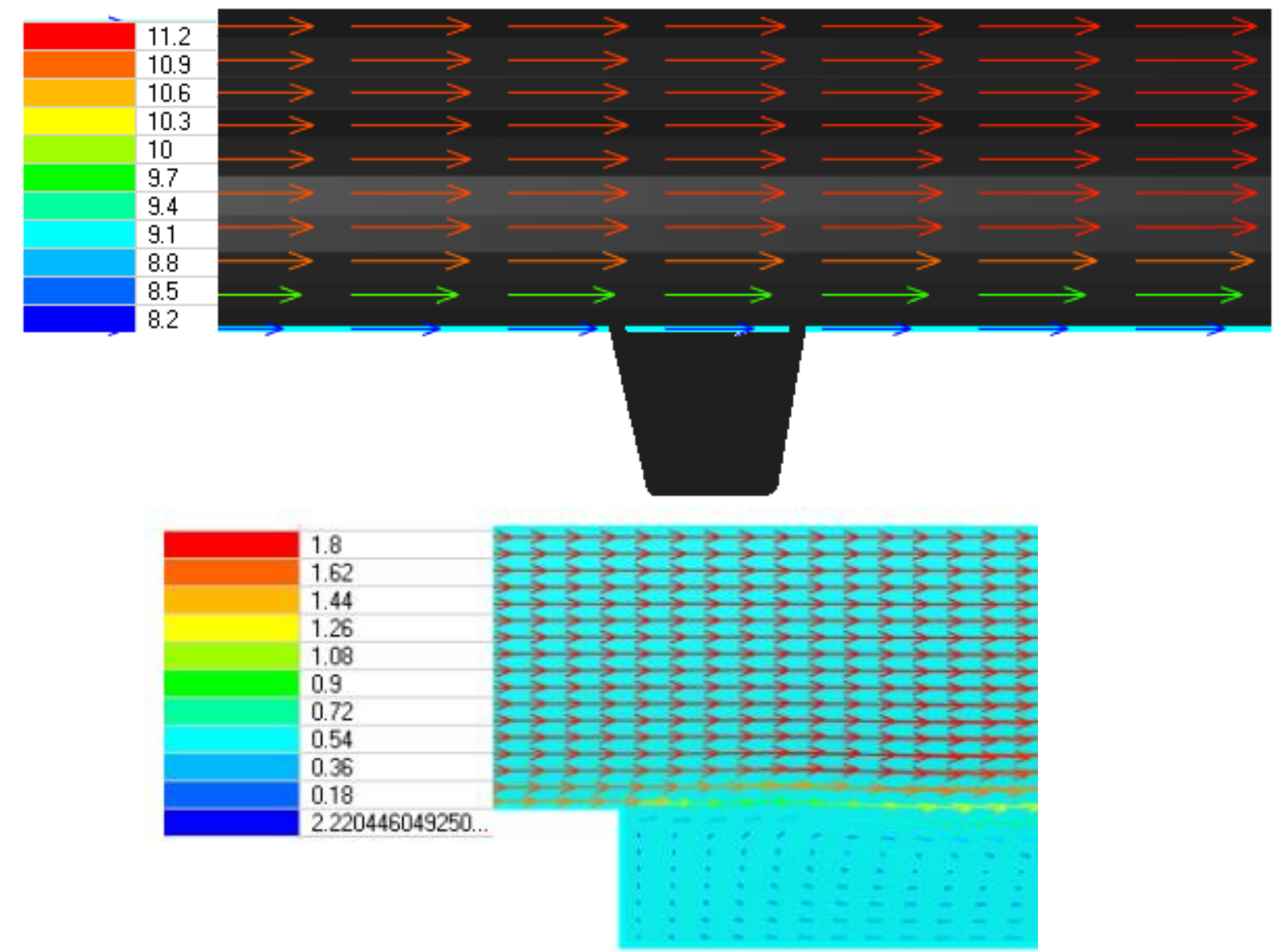

Picture 4 -Velocity distribution.

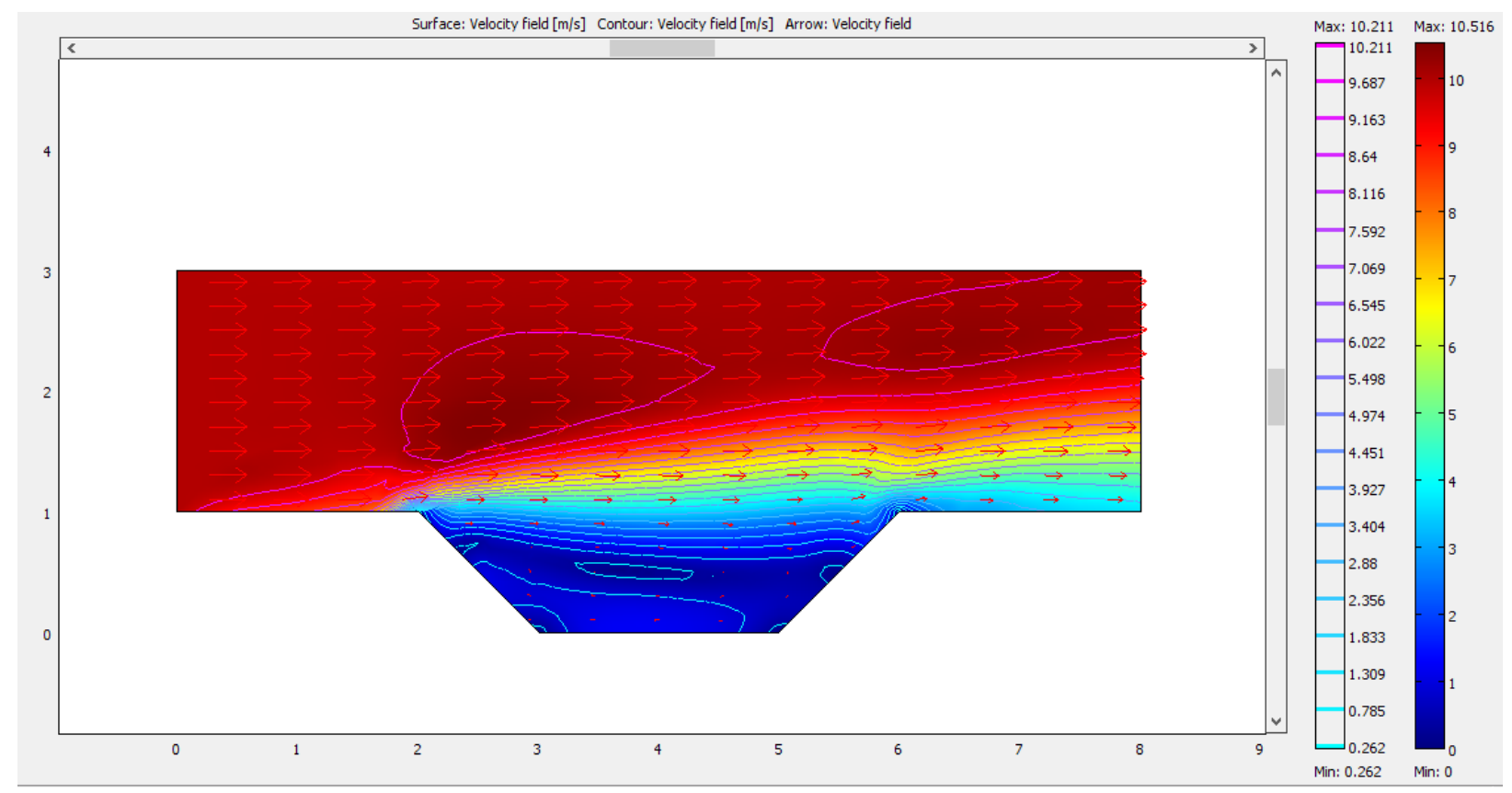

Picture 5 - The distribution of velocity and pressure in the wind to $10 \mathrm{~m} / \mathrm{s}$. 


\begin{tabular}{|c|c|c|c|c|c|c|}
\hline Impact Factor: & $\begin{array}{l}\text { ISRA (India) } \\
\text { ISI (Dubai, UAE } \\
\text { GIF (Australia) } \\
\text { JIF }\end{array}$ & $\begin{array}{l}=1.344 \\
=0.829 \\
=0.564 \\
=1.500\end{array}$ & $\begin{array}{l}\text { SIS (USA) } \\
\text { PИНЦ (Russia) } \\
\text { ESJI (KZ) } \\
\text { SJIF (Morocco) }\end{array}$ & $\begin{array}{l}=0.912 \\
=0.207 \\
=4.102 \\
=\mathbf{2 . 0 3 1}\end{array}$ & $\begin{array}{l}\text { ICV (Poland) } \\
\text { PIF (India) } \\
\text { IBI (India) }\end{array}$ & $\begin{array}{l}=6.630 \\
=1.940 \\
=4.260\end{array}$ \\
\hline
\end{tabular}

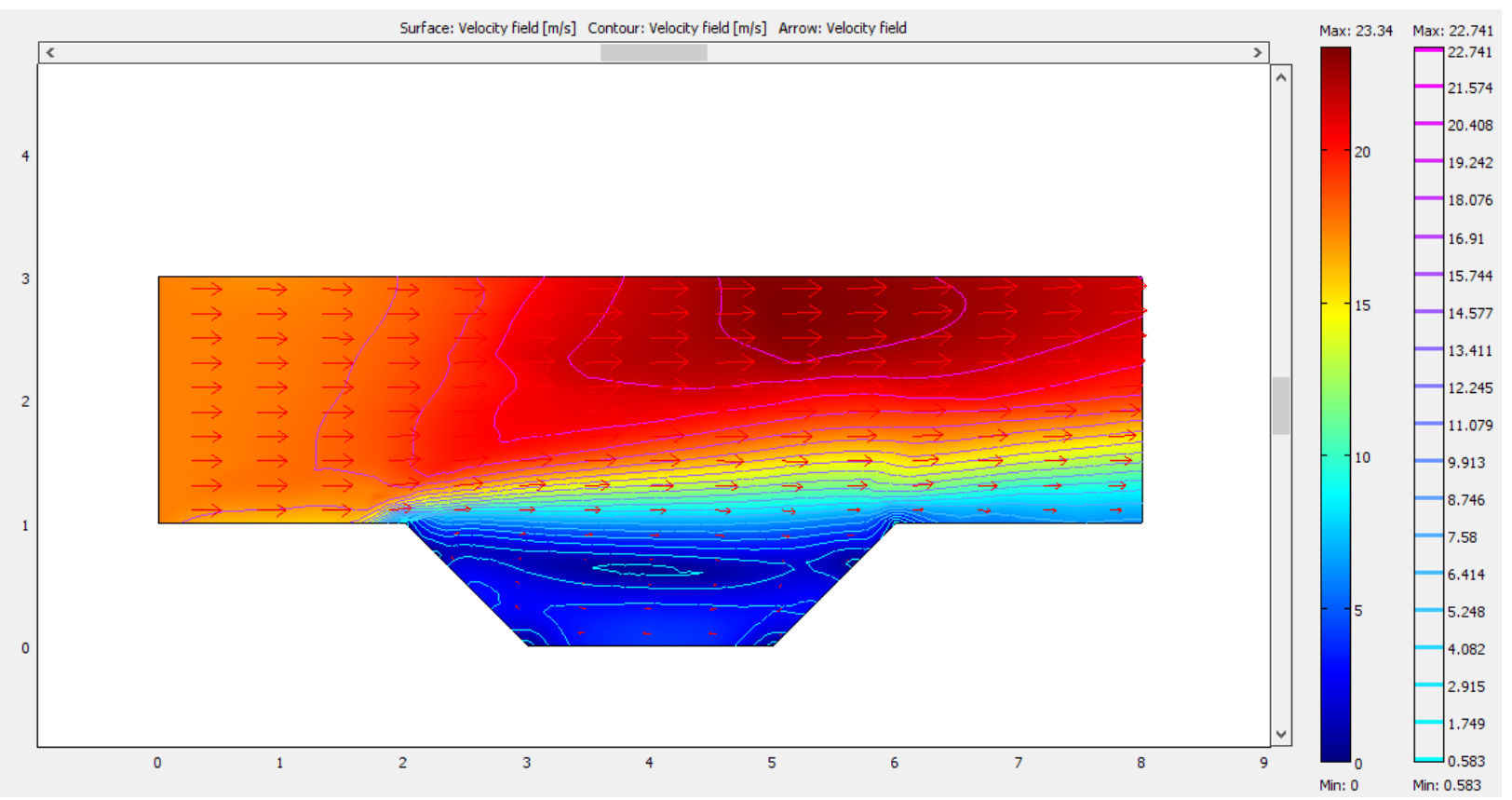

Picture 6 - The distribution of velocity and pressure in the wind to $20 \mathrm{~m} / \mathrm{s}$

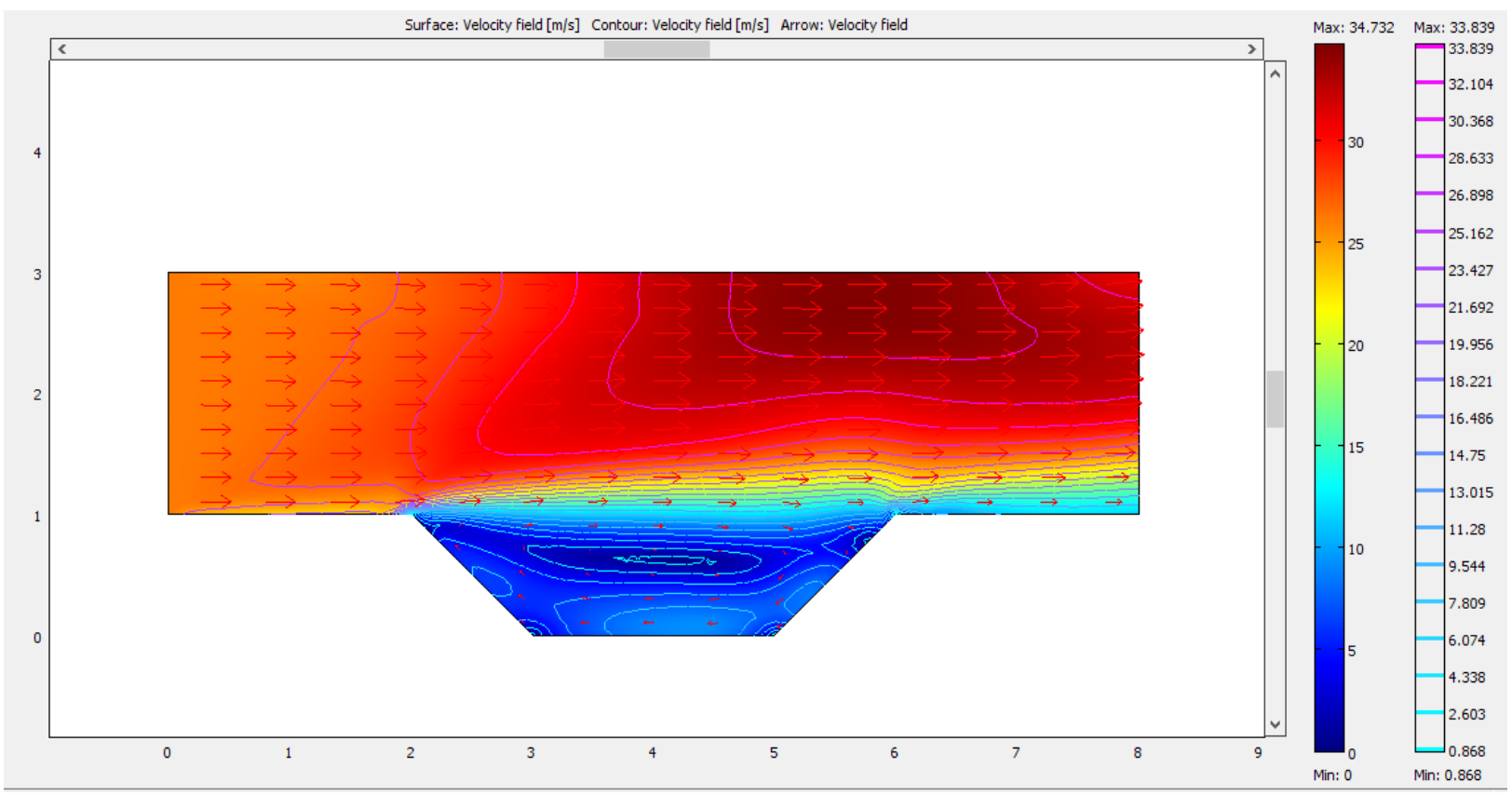

Picture 7 - The distribution of velocity and pressure in the wind to $30 \mathrm{~m} / \mathrm{s}$

ISPC Generalization of scientific results, 


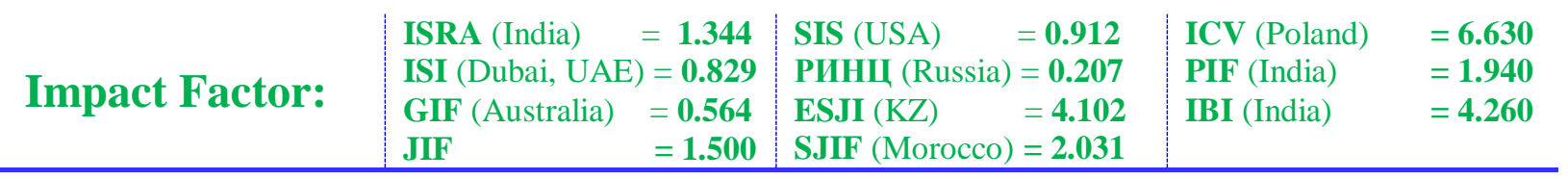

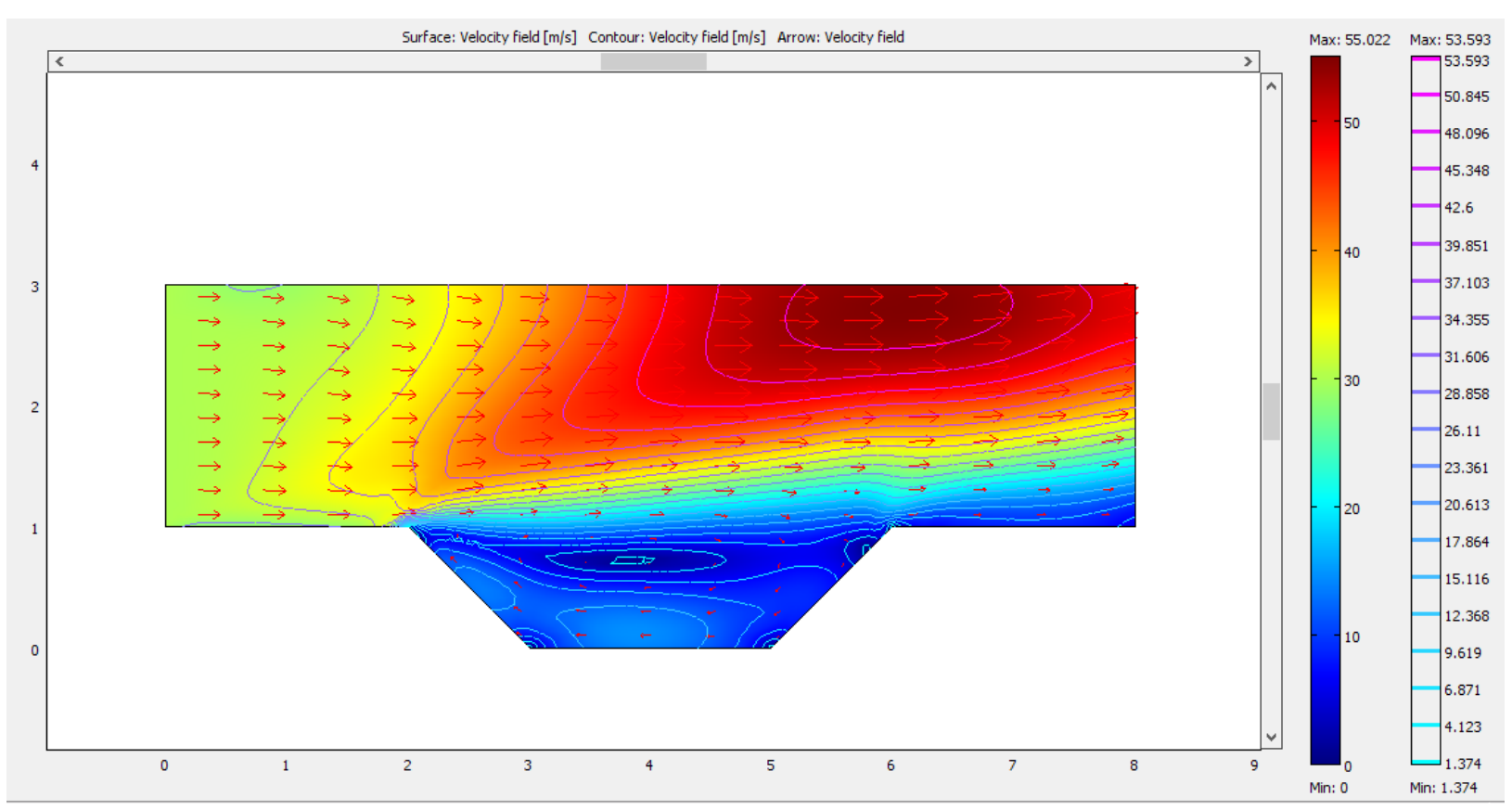

Picture 8 - The distribution of velocity and pressure in the wind to $40 \mathrm{~m} / \mathrm{s}$

\section{Conclusion}

A mathematical model of the flow around an empty channel. The obtained aerodynamic characteristics of modeling process air flow with uniform wind and wind gusts from 10 to $40 \mathrm{~m} / \mathrm{s}$. the data Obtained can be used in the analysis and modeling of snow-sensimet and deflation of soils.

\section{References:}

1. Koybakov SM, Zhunisbekov S, Shevtsov AN (2015) ABOUT MODEL AERODYNAMIC FLOW CHANNEL. ISJ Theoretical \& Applied Science $01 \quad$ (21): 190-197. doi: http://dx.doi.org/10.15863/TAS.2015.01.21.32

2. (1984) Ograzhdenie dlya zashchity ob"ektov ot snezhnykh zanosov. Patent № SU1237735A1.

3. (2015) Vyazkost'. Available: https://ru.wikipedia.org/wiki/\%C2\%FF\%E7\%E A\%EE\%F1\%F2\%FC (Accessed:25.01.15).

4. (2015) Dinamicheskaya vyazkost' gazov i parov. Available: http://thermalinfo.ru/publ/gazy/gazy raznye/din amicheskaja_vjazkost_gazov_i_parov/29-1-0316 (Accessed:25.01.15).

5. Koybakov S.M. (2013) Izobreteniya v oblasti gidrotekhniki $\mathrm{i}$ bezopasnosti zhiznedeyatel'nosti. -Taraz, TarGU, Taraz unversiteti, $-2013,112 \mathrm{c}$.

6. (2015) Srednyaya skorost' vetra v regionakh Respubliki Kazakhstan. Available:
http://www.energywind.ru/recomendacii/Skoros t-vetra-Kazakhstan (Accessed:25.01.15).

7. Zhunisbekov S, Koybakov SM, Shevtsov AN (2014) SOME FEATURES OF MATHEMATICAL MODELING OF COASTAL MANAGERITALIA. ISJ Theoretical \& Applied Science 07 (15): 36-42. doi:

http://dx.doi.org/10.15863/TAS.2014.07.15.6

8. Shevtsov AN, Alimbaev BA, Manapbaev BZ (2013) COMPUTER MODEL OF THE INFLUENCE OF MAGNETIC FIELDS OF THE DOMAINS IN THE FORM OF MICROCRACKS AT FRACTURE OF METALS. ISJ Theoretical \& Applied Science 06 (2): 51-64. doi:

http://dx.doi.org/10.15863/TAS.2013.06.2.6

9. Shevtsov AN (2014) SOME QUESTIONS SIMULATION OF INTERACTIVE DYNAMIC SYSTEMS. ISJ Theoretical \& 


\begin{tabular}{|c|c|c|c|c|c|c|}
\hline Impact Factor: & $\begin{array}{l}\text { ISRA (India) } \\
\text { ISI (Dubai, UAE } \\
\text { GIF (Australia) } \\
\text { JIF }\end{array}$ & $\begin{array}{l}=1.344 \\
=0.829 \\
=0.564 \\
=1.500\end{array}$ & $\begin{array}{l}\text { SIS (USA) } \\
\text { PИНЦ (Russia) } \\
\text { ESJI (KZ) } \\
\text { SJIF (Morocco) }\end{array}$ & $\begin{array}{l}=0.912 \\
=0.207 \\
=4.102 \\
=2.031\end{array}$ & $\begin{array}{l}\text { ICV (Poland) } \\
\text { PIF (India) } \\
\text { IBI (India) }\end{array}$ & $\begin{array}{l}=6.630 \\
=1.940 \\
=4.260\end{array}$ \\
\hline
\end{tabular}

Applied Science $01 \quad$ (9): 5-22. doi: http://dx.doi.org/10.15863/TAS.2014.01.9.2

10. (2015) Raschet koeffitsienta dinamicheskoy vyazkosti gaza. Available: http://www.chemway.ru/bd_chem/definition/me thods/desc_gas/mu_calc.php

(Accessed:25.01.15).

11. (2015)Vikhrerazreshayushchee modelirovanie kak odin iz metodov opisaniya turbulentnykh techeniy. Available: http://www.inm.ras.ru/laboratory/direct2.htm (Accessed:25.01.15).
12. (2015) URAVNENIYa REYNOL"DSA DLYa OSREDNENNOGO TURBULENTNOGO DVIZhENIYa. Available: http://studopedia.net/6_34965_uravneniyareynoldsa-dlya-osrednennogo-turbulentnogodvizheniya.html (Accessed:25.01.15).

13. Sugak EV, Sugak AV (2013) MODELIROVANIE TURBULENTNYKh ZAKRUChENNYKh POTOKOV. Available: http://www.science-education.ru/107-8312 (Accessed:25.01.15). 